\title{
Occurrence of termites (Isoptera) on living and standing dead trees in a tropical dry forest in Mexico
}

\author{
Nancy Calderón-Cortés ${ }^{\text {Corresp., }}{ }^{1}$ ， Luis H. Escalera-Vázquez ${ }^{2}$ ， Ken Oyama ${ }^{1}$ \\ ${ }^{1}$ Escuela Nacional de Estudios Superiores Unidad Morelia, Universidad Nacional Autónoma de México, Morelia, Michoacán, Mexico \\ 2 CONACyT, Instituto de Investigaciones sobre los Recursos Naturales, Universidad Michoacana de San Nicolás de Hidalgo, Morelia, Michoacán, México \\ Corresponding Author: Nancy Calderón-Cortés \\ Email address: ncalderon@enesmorelia.unam.mx
}

Termites play a key role as ecosystem engineers in numerous ecological processes although their role in the dynamics of wood degradation in tropical dry forests, particularly at the level of the crown canopy, has been little studied. In this study, we analysed the occurrence of termites in the forest canopy by evaluating the density and proportion of living and standing dead trees associated with termites in deciduous and riparian habitats of the tropical dry forest in Chamela, Mexico. The results indicated that $60-98 \%$ of standing dead trees and $23-59 \%$ of living trees in Chamela were associated with termites. In particular, we found that the density of standing dead trees was higher in deciduous forests $\left(0.057-0.066\right.$ trees $\left./ \mathrm{m}^{2}\right)$ than in riparian forests $\left(0.022\right.$ and 0.027 trees $\left./ \mathrm{m}^{2}\right)$, even though the proportion of trees was not significantly different among habitats. Additionally, we found a higher density of trees associated with termites in trees of smaller size classes (0.01-0.09 trees $\left./ \mathrm{m}^{2}\right)$ than in larger class sizes (0-0.02 trees $\left./ \mathrm{m}^{2}\right)$. Interestingly, $72 \%$ of variation in the density of trees associated with termites is explained by the density of standing dead trees. Overall, these results indicate that standing dead tree availability might be the main factor regulating termite populations in Chamela forest and suggest that termites could play a key role in the decomposition of above-ground dead wood, mediating the incorporation of suspended and standing dead wood into the soil. 
1 Occurrence of termites (Isoptera) on living and standing dead trees in a tropical dry forest

2 in Mexico

3

4 Nancy Calderón-Cortés, Escuela Nacional de Estudios Superiores Unidad Morelia, Universidad

5 Nacional Autónoma de México, Morelia, Michoacán, México.

6

7 Luis H. Escalera-Vázquez, CONACyT, Instituto de Investigaciones sobre los Recursos

8 Naturales, Universidad Michoacana de San Nicolás de Hidalgo, Morelia, Michoacán, México.

9

10 Ken Oyama, Escuela Nacional de Estudios Superiores Unidad Morelia, Universidad Nacional

11 Autónoma de México, Morelia, Michoacán, México.

12

13 Corresponding author:

14

15 Nancy Calderón-Cortés

16 Email: ncalderon@enesmorelia.unam.mx

17

18

19

20

21

22

23

24 


\section{ABSTRACT}

27

28 Termites play a key role as ecosystem engineers in numerous ecological processes although their

29 role in the dynamics of wood degradation in tropical dry forests, particularly at the level of the

30 crown canopy, has been little studied. In this study, we analysed the occurrence of termites in the

31 forest canopy by evaluating the density and proportion of living and standing dead trees

32 associated with termites in deciduous and riparian habitats of the tropical dry forest in Chamela,

33 Mexico. The results indicated that $60-98 \%$ of standing dead trees and $23-59 \%$ of living trees in

34 Chamela were associated with termites. In particular, we found that the density of standing dead 35 trees was higher in deciduous forests $\left(0.057-0.066\right.$ trees $\left./ \mathrm{m}^{2}\right)$ than in riparian forests $(0.022$ and

360.027 trees $/ \mathrm{m}^{2}$ ), even though the proportion of trees was not significantly different among

37 habitats. Additionally, we found a higher density of trees associated with termites in trees of

38 smaller size classes $\left(0.01-0.09\right.$ trees $\left./ \mathrm{m}^{2}\right)$ than in larger class sizes $\left(0-0.02\right.$ trees $\left./ \mathrm{m}^{2}\right)$. Interestingly,

$3972 \%$ of variation in the density of trees associated with termites is explained by the density of

40 standing dead trees. Overall, these results indicate that standing dead tree availability might be

41 the main factor regulating termite populations in Chamela forest and suggest that termites could

42 play a key role in the decomposition of above-ground dead wood, mediating the incorporation of

43 suspended and standing dead wood into the soil.

46 INTRODUCTION

47 The decomposition of organic matter stands out as a central component of ecosystem

48 functioning, playing important roles related to nutrient cycling and energy flow and influencing

49 the diversity in ecosystems (Murphy \& Lugo, 1986). Termites (Blattaria: Isoptera) represent one 
50 of the most important groups of organisms that participate in organic matter decomposition in

51 tropical ecosystems since they constitute from $40-95 \%$ of the total biomass of soil macrofauna

52 (Dangerfield, McCarthy \& Ellery, 1998; Donovan et al., 2007). The role of termites in ecosystem

53 processes in tropical forests has been widely documented, demonstrating that termites regulate

54 the incorporation and decomposition of organic matter to the soil, contribute to carbon and

55 nitrogen mineralization, alter vegetation composition, and improve soil structure by increasing

56 porosity, aeration, and water retention (Aanen et al., 2002; Dawes-Gromadzki, 2003; Ohkuma,

57 2003; Jeyasingh \& Fuller, 2004; Donovan et al., 2007; Erpenbach et al., 2013; Dahlsjo et al.,

58 2014; Houston, Wormington \& Black, 2015; Maynard et al., 2015). Therefore, in these

ecosystems, termites are recognized as keystone ecosystem engineers that directly or indirectly

modify the availability of nutrients for other organisms through the decomposition of plant

material (Dangerfield, McCarthy \& Ellery, 1998; Bignell, 2006; Moe, Mobæk \& Narmo, 2009;

62 Jouquet et al., 2011; Romero et al., 2014), particularly when termites incorporate dead woody

63 material suspended in the forest canopy (i.e., standing dead trees and fallen trunks and branches)

64 that is otherwise inaccessible to soil micro- and macro-fauna (Maynard et al., 2015).

65 Coarse woody debris (CWD) is an important dead-wood component of tropical forests, and therefore of the decomposition process, that can represent as much as $42 \%$ of the above-

67 ground biomass (Clark et al., 2004; Rice et al., 2004; Pfeifer et al., 2015). The decomposition of woody material is usually considered to be primarily a forest-floor process because the contact of plant debris with organisms in the soil, as well as with the suitable micro-environmental conditions of the soil interface, increases the decomposition rates (Harmon et al., 1986). In contrast, it is assumed that higher irradiance and windy conditions in the upper canopy create a drier environment that limits the type and abundance of decomposers, thereby reducing the rate 
73 of decomposition of woody material (Harmon et al., 1986; Fonte \& Schowalter, 2004). However,

74 in some subtropical dry forests, it has been found that approximately three-quarters of the

75 available pieces of dead wood in the forest canopy (i.e., standing dead trees and suspended dead

76 wood in the crown of trees) present signs of termite activity (Jones et al., 1995). Indeed, the role

77 of termites in decomposing standing dead wood has been recognized for nearly 100 years in

78 temperate forests (Maynard et al., 2015, and references therein), but its role in the decomposition

79 process of dead woody material at the canopy level (i.e., dead wood above-ground) has been

80 poorly studied in tropical forests. In particular, the role of termites in wood decomposition has

81 not been investigated in tropical forests of Mexico (Méndez-Montiel \& Equihua-Martínez, 2001;

82 Maass et al., 2002; Rodríguez-Palafox \& Corona, 2002).

83 In this study, we recorded the presence of termites on living and standing dead trees in a

84 tropical dry forest in Chamela, Jalisco, to illuminate the role that termites could play in the

85 decomposition of above-ground dead woody material of a tropical dry forest in Mexico. The

86 diversity of termites in the Chamela forest is represented by 30 species belonging to three

87 families: Kalotermitidae (10 spp.), Rhinotermitidae (2 spp), and Termitidae (18 spp), including

88 species feeding on dry wood, decaying wood and humus (i.e., soil feeders) (Nickle \& Collins,

89 1988; Rodríguez-Palafox \& Corona, 2002). Based on independent annual estimations, it is

90 known that dead woody material in the tropical dry forest in Chamela comprises approximately

$9132 \%$ of total biomass aboveground (Duran et al., 2002; Segura et al., 2003). From this, 20-53\%

92 represents dead wood in the forest floor, and 46-80\% represents standing dead trees and

93 suspended branches (Duran et al., 2002; Maass et al., 2002; Segura et al., 2003), indicating that

94 decomposition of suspended and standing dead wood is critical for this forest. The presence of

95 all major termite groups in Chamela, including wood dwelling and carton-nest building species 
96 (Nickle \& Collins, 1988), and the occurrence of termite galleries in most of the standing dead

97 trees, suggest that termites play an important role in decomposing wood in the forest canopy

98 (Maass et al., 2002). To our knowledge, the present study represents the first approach to analyse

99 the occurrence of termites on living and standing dead trees to illuminate the potential role that

100 termites play in the decomposition of above-ground dead woody material in a tropical dry forest

101 in Mexico. In particular, we addressed the following questions: i) What is the density of trees

102 associated with termites?; ii) Is the density of living and standing dead trees associated with

103 termites different between deciduous and riparian habitats?; iii) What is the proportion of living

104 and standing dead trees associated with termites?; iv) Are these proportions different between

105 habitats?; v) Does tree size determine the association with termites?; and vi) Does the density of

106 standing dead trees explain the presence of termites in trees?.

107

108 MATERIALS AND METHODS

109 Study site

110 The study was conducted the during rainy season (October) in 2004 and 2009 at the Chamela

111 Biological Station, UNAM ( $\left.19^{\circ} 30^{\prime} \mathrm{N}, 105^{\circ} 03^{\prime} \mathrm{W}\right)$, located in the state of Jalisco, Mexico, 2

$112 \mathrm{~km}$ east of the Pacific coast. The climate is warm with a mean annual temperature of $24.6^{\circ} \mathrm{C}$ and

113 an annual rainfall of $748 \mathrm{~mm}$ (Lott, Bullock \& Solís-Magallanes, 1987). This ecosystem presents

114 a marked seasonality, with a dry season from November to May (when the forest canopy is lost)

115 and a rainy season from June to October (García-Oliva, Camou \& Maass, 2002). The dry forest,

116 located on upland soils, is dominated by deciduous trees of 4-15 $\mathrm{m}$ in height, with a well-

117 developed understory of shrubs and some patches of tropical riparian forest associated with

118 intermittent streams (Rzedowski, 1978; Lott, Bullock \& Solís-Magallanes, 1987). The landscape 
119 consists of low hills (50-160 m elevation) with steep convex slopes with alluvial and sandy soils

120 of variable deep (García-Oliva, Camou \& Maass, 2002; Jaramillo et al., 2003).

121

122 Methods

123 We sampled five plots of $200 \mathrm{~m}^{2}(4 \times 50 \mathrm{~m})$ in each habitat (i.e., deciduous and riparian forest)

124 for each year. The plots were randomly selected next to the paths in the biological station but 125 oriented perpendicular to the path to reduce the border effect. Within each plot, we registered

126 living and standing dead trees, with and without termite activity signs (i.e., the presence of

127 galleries). The diameter at breast height $(\mathrm{DBH}=1.3 \mathrm{~m})$ of each tree was measured; for multi-

128 stemmed trees, DBH was calculated as the sum of each stem measure. The collected termite

129 samples we conserved in ethanol $70 \%$ for further identification to the lowest taxonomic level

130 based on Nickle \& Collins (1988).

132 Data analysis

133 We estimated the density of living and standing dead trees with and without termites in each plot

134 as the total number of trees divided by the plot area $\left(200 \mathrm{~m}^{2}\right)$. To evaluate the effect of habitat on

135 the density trees with and without termites, we analysed the density of living and standing dead

136 trees using the GENMOD procedure with a Poisson distribution and logarithmic link function.

137 The model used tree density as the dependent variable and habitat (deciduous and riparian), year

138 and the interaction between habitat and year as independent variables.

139 To determine the proportion of trees associated with termites, we registered the

140 presence/absence of termites in living and standing dead trees in the two habitats. Data were

141 analysed using the GENMOD procedure, with a binomial distribution, logistic link function and 
142 descending option (i.e., modelling the probability of termite presence). The presence of termites

143 was used as the dependent variable; meanwhile, habitat, year and the interaction between habitat

144 and year were fixed as independent variables. DBH was used as a covariate.

145 In addition, to evaluate the effect of tree size on the density of living and standing dead

146 trees with and without termites, we classified all trees inside plots into different size classes: I

147 saplings $(\mathrm{DBH} \leq 5 \mathrm{~cm})$; II juveniles $(\mathrm{DBH}>5 \leq 15 \mathrm{~cm}) ;$ III medium adults $(\mathrm{DBH}>15 \leq 25$

$148 \mathrm{~cm})$; and IV large adults $(\mathrm{DBH}>25 \mathrm{~cm})$. The density of living and standing dead trees with and

149 without termites was analysed using the GENMOD procedure with a Poisson distribution and

150 logarithmic link function for each year; density was used as the dependent variable, while size

151 class (saplings, juveniles, medium adults and large adults) and the interaction between size class

152 and habitat were used as independent variables. Finally, we performed a linear regression

153 analysis (GLM procedure) to evaluate whether the density of standing dead trees is related to the

154 density of trees associated with termites. All statistical analyses were performed using SAS

155 software (SAS Institute, 2017).

156

157 RESULTS

158 Termites and habitat parameters

159 The termite species collected on trees in the Chamela forest were Nasutitermes nigriceps, $N$.

160 mexicanus and Amitermes spp (Termitidae). The Nasutitermitinae species were frequently

161 collected from galleries in both living and standing dead trees and from cartoon nests, while

162 Amitermes spp. were collected from the interior of standing dead trees.

163 Our results showed that habitat $\left(\mathrm{F}_{1,16}=2.21, P=0.1569\right)$ and habitat*year interaction $\left(\mathrm{F}_{1}\right.$,

$164{ }_{16}=0.11, P=0.7423$ ) did not affect the density of living trees, although the density of living 
165 trees was significantly higher in 2009 than in $2004\left(\mathrm{~F}_{1,16}=16.97, P=0.0008\right.$; Table 1). The

166 opposite pattern was found for standing dead trees: habitat significantly affected tree density $\left(\mathrm{F}_{1}\right.$,

$\left.167{ }_{16}=9.14, P=0.0081\right)$, but neither year $\left(\mathrm{F}_{1,16}=3.98, P=0.0633\right)$ nor the habitat*year interaction

$168\left(\mathrm{~F}_{1,16}=0.26, P=0.6177\right)$ had a significant effect on tree density. Deciduous forest showed a

169 higher density of standing dead trees than riparian forest (Table 1).

170 We also found that tree size class had a significant effect on the density of both living $\left(\mathrm{F}_{3}\right.$,

$17132=11.00, P<0.0001)$ and standing dead trees $\left(\mathrm{F}_{3,32}=5.60, P=0.003\right)$. High densities of living

172 trees were found in smaller size classes (I and II), but the size class with the highest tree density

173 differed in each year: size class I in 2004, and size class II in 2009 (Table 1). In the case of

174 standing dead trees, size class II show the highest tree density, followed by size class I (Table 1).

175 This pattern was consistent across years. The size class * habitat interaction was not significant in

176 any year for both living and standing dead trees $\left(2004: \mathrm{F}_{3,32}=0.46, P=0.7126\right.$ and $\mathrm{F}_{3,32}=0.06$,

$177 P=0.9824 ; 2009: \mathrm{F}_{3,32}=0.11, P=0.9518$ and $\mathrm{F}_{3,32}=0.65, P=0.5909$, respectively).

178

179 Interaction of termites with trees

180 There was a significant difference in the density of living trees associated with termites between

181 habitats $\left(\chi^{2}=8.15, P=0.0043\right)$ and years $\left(\chi^{2}=8.15, P=0.0043\right)$, but the habitat*year interaction

182 did not show a significant difference $\left(\chi^{2}=0.69, P=0.4071\right)$. The density of living trees

183 associated with termites was higher in deciduous (0.091 and 0.19 trees $/ \mathrm{m}^{2}$ for 2004 and 2009,

184 respectively) than in riparian forest $\left(0.061\right.$ and 0.091 trees $/ \mathrm{m}^{2}$ for 2004 and 2009 , respectively;

185 Fig. 1A), although a significant difference was only found in 2009 (Fig. 1A). Similarly, the

186 density of standing dead trees associated with termites showed a significant difference between

187 habitats $\left(\chi^{2}=15.29, P<0.0001\right)$, with a higher density in deciduous $\left(0.057\right.$ and 0.066 trees $/ \mathrm{m}^{2}$ 
188 for 2004 and 2009, respectively) than in riparian forest $\left(0.022\right.$ and 0.027 trees $/ \mathrm{m}^{2}$ for 2004 and

189 2009, respectively; Fig. 1B), although there was no significant effect of year $\left(\chi^{2}=0.5 P=\right.$

$1900.4788)$ or the habitat*year interaction $\left(\chi^{2}=0.01 P=0.9068\right)$ (Fig. 1B).

191 In total we registered the presence/absence of termites in 1334 trees. Our results indicated

192 that habitat did not have a significant effect on the proportion of living trees associated with

193 termites $\left(\chi^{2}=0.02, P=0.8986\right.$; Fig. 2 A $)$. However, year $\left(\chi^{2}=55.06, P<0.0001\right)$, the

194 habitat*year interaction $\left(\chi^{2}=10.02, P=0.0016\right)$, and $\mathrm{DBH}\left(\chi^{2}=20.05, P<0.0001\right)$ showed a

195 significant effect on the proportion of living trees associated with termites, with a greater

196 percentage of living trees associated with termites in 2004 than in 2009 in both habitats (Fig.

197 2A). On the other hand, the proportion of standing dead trees associated with termites was

198 significantly affected by year $\left(\chi^{2}=16.05, P<0.0001\right)$ and $\mathrm{DBH}\left(\chi^{2}=4.43, P=0.0353\right)$, but

199 there was no significant effect by habitat $\left(\chi^{2}=3.8, P=0.0512\right)$ or by the habitat*year interaction

$200\left(\chi^{2}=0.03, P=0.8729\right)$ (Fig. 2B). Similar to living trees, the proportion of standing dead trees

201 associated with termites was greater in 2004 than in 2009 (Fig. 2B).

202 Size class showed a significant effect on the density of both living and standing dead

203 trees associated with termites in both years $\left(2004: \mathrm{F}_{3,32}=10.56, P<0.0001\right.$ and $\mathrm{F}_{3,32}=5.01, P=$

$2040.0058 ; 2009: \mathrm{F}_{3,32}=8.58, P=0.0003$ and $\mathrm{F}_{3,32}=16.54, P<0.0001$ for living and standing dead

205 trees, respectively). However, the size class*habitat interaction did not affect either the density of

206 living trees or the density of standing dead trees in any year. In general, the density of living and

207 standing dead trees was significantly higher in size class II, followed by size class I, size class III 208 and size class IV, in both habitats and years (Fig. 3A, 3B).

209 Finally, our results indicated that the density of standing dead trees was positively related

210 to the density of trees associated with termites $\left(\mathrm{R}^{2}=0.72, \mathrm{~F}_{1,20}=47.65, P<0.0001\right.$; Fig. 4). 


\section{DISCUSSION}

213 Termites are among the invertebrates with the largest biomass and abundance in tropical forests

214 (Bignell \& Eggleton, 2000; Vasconcellos, 2010). However, due to the great diversity of

215 microhabitats they occupy (i.e., soil, decomposing wood, leaf litter, arboreal or soil mounds,

216 inside the living trees and/or fallen branches that remain in the forest canopy), it is difficult to

217 evaluate the density of these insects in the forest (Eggleton et al., 1995). Termite density has

218 been estimated based on the number of encounters with termites in transects of $200 \mathrm{~m}^{2}$ (Davies,

219 1997; Eggleton et al., 1995, 1996; Crist, 1998; Inoue et al., 2006), based on nest volume

220 (Jeyasingh \& Fuller, 2004) and in controlled experiments using baits (Dawes-Gromadzki, 2003;

221 Davies et al,. 2015), although these estimations might not reflect the potential of colonization of 222 dead wood available in the forest canopy. In this study, we evaluated the occurrence of termites

223 on living and standing dead trees in a tropical dry forest based on the density and proportion of

224 trees in which termites are present, and in general, our results indicate that the availability of

225 standing dead trees is associated with the density of trees with termites.

226 Specifically, our results showed that the proportion of living and standing dead trees was

227 not different among habitats, indicating that habitat characteristics might not affect the termite

228 presence on trees. Nevertheless, we observed a general pattern of higher density of trees with

229 termite activity in deciduous than in riparian forest for both living and standing dead trees. This

230 pattern can be explained by the difference in resource availability (i.e., necromass) for termites,

231 which in turn can be related to the density and volume of dead wood present in each habitat.

232 Periodic inundations of riparian habitats can also control termite populations since flooding

233 events reduce termite populations, particularly subterranean termites (Ulyshen 2014). However, 
234 it is unknown whether flooding events can negatively affect arboreal termites such as Termitidae 235 species.

236 Necromass includes either suspended and soil wood materials, as well as standing dead

237 material (Harmon et al., 1986). However, standing dead trees or snags constitute an important

238 component of necromass (46-80\%) in Chamela forest (Duran et al., 2002; Maass et al., 2002).

239 Interestingly, our results indicate that $60-98 \%$ of standing dead trees in Chamela were associated

240 with termites, and similar to a previous study evaluating the density and proportion of standing

241 dead trees in Chamela (Segura et al., 2003), our results also indicated that the density of standing

242 dead trees was higher in deciduous (600-870 trees/ha) than in riparian forest (250-470 trees/ha).

243 In addition, the density of both living and standing dead trees associated with termites was also

244 higher in trees of smaller class sizes $(<15 \mathrm{~cm} \mathrm{DBH})$, for which we also found a higher density of

245 standing dead trees. High mortality rates in small trees $(<10 \mathrm{~cm}$ of DBH $)$ have been reported for

246 other tropical ecosystems (Bellingham \& Tanner, 2000; Lorimer, Dahir \& Nordheim, 2001;

247 Clark et al., 2004). Overall, these results suggest that standing dead tree availability might be the

248 main factor regulating termite occurrence in Chamela forest. This hypothesis was confirmed by

249 the positive relationship found between the density of standing dead trees and the density of trees

250 associated with termites $\left(\mathrm{r}^{2}=0.72\right)$. There is available evidence indicating positive correlations

251 between the volume of dead wood and the volume of termite nests (i.e., as a surrogate of termite

252 density; Jones et al., 1995; Jeyasingh \& Fuller, 2004), but interestingly, a positive correlation

253 between standing dead wood and termite density at a broad regional scale (i.e., the USA) has

254 been recently reported (Maynard et al., 2015). A positive relationship between dead wood and

255 insect density has also been reported for saproxylic borer beetles (Grove et al., 2002; Lachat et

256 al., 2012). 

over temporal and spatial scales (Martius, 1997; Palace et al., 2012). Several factors and mechanisms have been reported to explain this variation (i.e., tree competition for nutrients and 260 light, topography, root system characteristics of trees, among others), but disturbance appears to 261 play a prominent role (Martínez-Ramos et al., 1988; Gale, 2000; Palace et al., 2012). In this

262 sense, habitats subjected to frequent disturbance are expected to have high necromass production 263 (Palace et al., 2012). In Chamela forest, such disturbance events are reported to be associated 264 with drought followed by wind throw related to frequent tropical summer storms (García-Oliva, 265 Martínez-Lugo \& Maass, 1995), but it is recognized that drought events play a key role in tree 266 mortality in this forest, particularly at higher elevation sites, such as deciduous forests, where the 267 driest conditions prevailed (García-Oliva, Martínez-Lugo \& Maass, 1995; Duran et al., 2002;

268 Maass et al., 2002), explaining the high proportion of standing dead trees we found in deciduous

269 forest. However, our results also indicated that termites are present in a considerable proportion 270 of living trees (23-59\%), suggesting that termites present in these trees are using dead branches 271 suspended in the forest canopy. The decomposition of both standing and suspended dead wood is 272 crucial in the dynamics of nutrient and energy flux in the ecosystem (Harmon et al., 1986). As 273 we mentioned before, in Chamela forest, the biomass of standing dead trees and suspended 274 branches (46-80\%) exceeds the biomass of dead wood in the forest floor (20-53\%), and in some 275 sites, it exceeds the biomass of litter (Maass et al., 2002; Jaramillo et al., 2003), indicating that 276 the decomposition of suspended and standing dead wood is critical for this forest (Maass et al., 277 2002). Standing and suspended dead wood are also an important component of total necromass 278 in other tropical ecosystems, reaching $66 \%$ in undisturbed forests and $98 \%$ in sites with high 279 disturbance levels (review in Palace et al., 2012). 

incorporation of suspended dead wood to the forest floor (Harmon et al., 1995; Maass et al.,

282 2002). However, the presence of termites, fungi and saproxylic beetles have been suggested as

283 the main factors related to the decomposition process of dead wood in the forest canopy (Swift et

284 al., 1976; Fonte \& Schowalter, 2004; Maynard et al., 2015). The abundance of termites and

285 decay rates of dead wood in the canopy have not been investigated in Chamela forest (Maass et 286 al., 2002), but the presence of termites on a great proportion of living and standing dead trees

287 found in this study suggests that termites could be an important decay agent at the canopy level 288 in Chamela forest. Similar results were reported in subtropical dry forests in Mona Island, Puerto 289 Rico, where nearly three-quarters of the available pieces of dead wood showed signs of termite 290 attack (Jones et al., 1995). The decay process in the forest is important in determining carbon and 291 nutrient inputs into the ecosystem, but early stages of decay occurring at the canopy level are 292 particularly important since they determine the rate of wood debris incorporation into the soil, 293 with long-term effects on nutrient ecosystem dynamics (Fonte \& Schowalter, 2004; Maynard et 294 al., 2015). Termites can be responsible for a considerable proportion of carbon mineralization 295 (i.e., 20\%) and nitrogen input to the soil (i.e., as high as $0.5 \mathrm{~kg} \mathrm{~N} /$ ha per year: reviewed in 296 Maynard et al., 2015). In Chamela, 39\% and 49\% of $\mathrm{C}$ and $\mathrm{N}$ forest stocks are sequestered in 297 total above-ground necromass (Jaramillo et al., 2003), and given that termites are frequently 298 present in standing dead trees of this forest, it is possible that they contribute significantly to C 299 and $\mathrm{N}$ cycling. 300

301 CONCLUSIONS 
302 The high proportion of trees on which termites are present in Chamela tropical dry forest, the

303 patterns of density of trees with termites in different habitats and size classes of trees that vary in

304 necromass availability, and the positive relationship between the density of trees associated with

305 termites and the density of standing dead trees suggest that termites could be important agents in

306 wood decomposition at the canopy level in this forest. However, given that this study did not

307 estimate the abundance and/or degradation decay rates mediated by termites and that this insect

308 group has not been studied in tropical forests in Mexico, future studies that quantify wood

309 decomposition by termites at the canopy and floor levels and that estimate the abundance and

310 diversity patterns of termites in different habitats (specially in those habitats experienced changes

311 in land use) are needed to understand the role that termites play in tropical forests in Mexico,

312 particularly in a scenario of global change that threatens biodiversity and ecosystem processes.

313

\section{ACKNOWLEDGEMENTS}

315 The authors thank the Postgraduate Program of Biological Sciences of the UNAM, M. Quesada

316 and Y. Herrerías-Diego for valuable comments and suggestions during field work, and F.O.

317 Saavedra-Cazáres and T.G. Marques-Silva for field work support. Finally, we thank the Chamela

318 Biological Station, UNAM for facilities and logistical support.

\section{REFERENCES}

322 Aanen DK, Eggleton P, Rouland-Lefèvre C, Guldberg-Froslev T, Rosendahl S, Boomsma 
323

324

325

326

327

328

329

330

331

332

333

334

335

336

337

338

339

340

341

342

343

344

345

JJ. 2002. The evolution of fungus-growing termites and their mutualistic fungal symbionts. Proceedings of the National Academy of Sciences 99: 14887-14892. DOI: $10.1073 /$ pnas.222313099

Bellingham PJ, Tanner EVJ. 2000. The influence of topography on tree growth, mortality and recruitment in a tropical montane forest. Biotropica 32: 378-384. DOI:

$$
\text { 10.1111/j.1744-7429.2000.tb00484.x }
$$

Bignell DE, Eggleton P. 2000. Termites in ecosystems. In: Abe T, Bignell DE, Higashi M eds. Termites: evolution, sociality, symbioses, ecology. Berlin: Springer, 363-387.

Bignell DE. 2006. Termites as soil engineers and soil processors. In: König H, Varma A eds. Intestinal microorganisms of termites and other invertebrates. Berlin: Springer, 183220.

Clark DB, Soto-Castro C, Alfaro LD, Read JM. 2004. Quantifying mortality of tropical rain forest trees using high-spatial-resolution satellite data. Ecology Letters 7: 52-59. DOI: 10.1046/j.1461-0248.2003.00547.x

Crist TO. 1998. The spatial distribution of termites in shortgrass steppe: a geostatistical approach. Oecologia 114: $410-416$.

Dahlsjö CA, Parr CL, Malhi Y, Rahman H, Meir P, Jones DT, Eggleton P. 2014. First comparison of quantitative estimates of termite biomass and abundance reveals strong intercontinental differences. Journal of Tropical Ecology 30: 143-152. DOI: $10.1017 / \mathrm{S} 0266467413000898$

Dangerfield JM, McCarthy TS, Ellery WN. 1998. The mound-building termite Macrotermes michaelseni as an ecosystem engineer. Journal of Tropical Ecology 14: 507-520. DOI: $10.1017 / \mathrm{S} 0266467498000364$ 
346 Davies RG. 1997. Termite species richness in fire-prone and fire-protected dry deciduous dipterocarp forest in Doi Suthep-Pui National Park, northern Thailand. Journal of Tropical Ecology 13: 153-160. DOI: 10.1017/S0266467400010348

Davies AB, Eggleton P, van Rensburg BJ, Parr CL. 2015. Seasonal activity patterns of African savanna termites vary across a rainfall gradient. Insectes sociaux 62: 157-165. DOI: $10.1007 / \mathrm{s} 00040-014-0386-\mathrm{y}$

352

Dawes-Gromadzki TZ. 2003. Sampling subterranean termite species diversity and activity in tropical savannas: an assessment of different bait choices. Ecological Entomology 28: 397-404. DOI: $10.1046 / j .1365-2311.2003 .00525 . x$

Donovan SE, Griffiths GJ, Homathevi R, Winder L. 2007. The spatial pattern of soil-dwelling termites in primary and logged forest in Sabah, Malaysia. Ecological Entomology 32: 1-10. DOI: 10.1111/j.1365-2311.2006.00856.x

Duran E, Balvanera P, Lott E, Segura G, Pérez-Jímenez A, Islas A, Franco M. 2002. Estructura, composición y dinámica de la vegetación. In: Noguera F, Vega-Rivera JH, García-Aldrete AN, Quesada M eds. Historia Natural de Chamela, México: Instituto de Biología-UNAM, 443-472.

Eggleton P, Bignell DE, Sands WA, Mawdsley NA, Lawton JH, Wood TG, Bignell NC. 1996. The diversity, abundance and biomass of termites under differing levels of disturbance in the Mbalmayo Forest Reserve, southern Cameroon. Philosophical Transactions of the Royal Society of London B 351: 51-68. DOI: 10.1098/rstb.1996.0004 Eggleton P, Bignell DE, Sands WA, Waite B, Wood TG, Lawton JH. 1995. The species 
richness of termites (Isoptera) under differing levels of forest disturbance in the Mbalmayo Forest Reserve, southern Cameroon. Journal of Tropical Ecology 11: 85- 98. DOI: $10.1017 / \mathrm{S} 0266467400008439$

370

Erpenbach A, Bernhardt-Römermann M, Wittig R, Thiombiano A, Hahn K. 2013. The influence of termite-induced heterogeneity on savanna vegetation along a climatic gradient in West Africa. Journal of Tropical Ecology 29: 11-23. DOI:

\section{$10.1017 / \mathrm{S} 0266467412000703$}

Fonte SJ, Schowalter TD. 2004. Decomposition in forest canopies. In: Lowman MD, Rinker HB eds. Forest canopies, Massachussetts: Elservier Academic Press, 413-422.

Gale N. 2000. The relationship between canopy gaps and topography in a western Ecuadorian rain forest. Biotropica 32: 653-661. DOI: 10.1111/j.17447429.2000.tb00512.x

García-Oliva F, Camou A, Maass JM. 2002. El clima de la región central de la Costa del Pacífico mexicano. In: Noguera F, Vega-Rivera JH, García-Aldrete AN, Quesada M eds. Historia Natural de Chamela, México: Instituto de Biología-UNAM, 3-10.

García-Oliva F, Maass JM, Galicia L. 1995. Rainstorm analysis and rainfall erosivity of a seasonal tropical region with a strong cyclonic influence on the Pacific Coast of Mexico. Journal of Applied Meteorology 34: 2491-2498. DOI: 10.1175/15200450(1995)034<2491\%3ARAAREO $>2.0 . \mathrm{CO} \% 3 \mathrm{~B} 2$

Grove SJ. 2002. Tree basal area and dead wood as surrogate indicators of saproxylic insect faunal integrity: a case study from the Australian lowland tropics. Ecological Indicators 1: 171-188. DOI: 10.1016/S1470-160X(01)00016-4

Harmon ME, Franklin JF, Swanson FJ, Sollins P, Gregory SV, Lattin JD, Anderson NH, 
Cline SP, Aumen NG, Sedell JR, Lienkaemper GW, Cromack K, Cummins KW. 1986.

Ecology of coarse woody debris in temperate ecosystems. Advances in Ecological

393 Harmon ME, Whigham DF, Sexton J, Olmsted I. 1995. Decomposition and Mass of

394 Woody Detritus in the Dry Tropical Forest of the Northeastern Yucatan Peninsula, Mexico. Biotropica 27: 305-316. DOI: 10.2307/2388916

Houston WA, Wormington KR, Black RL. 2015. Termite (Isoptera) diversity of riparian forests, adjacent woodlands and cleared pastures in tropical eastern Australia. Austral

Jaramillo VJ, Boone KJ, Rentería-Rodríguez L, Cummings DL, Ellingson LJ. 2003. Biomass, Carbon, and Nitrogen Pools in Mexican Tropical Dry Forest Landscapes. Ecosystems 6: 609-629. DOI: 10.1007/s10021-002-0195-4

Jeyasingh PD, Fuller CA. 2004. Habitat-specific life-history variation in the Caribbean

Jones SC, Nalepa CA, McMahan EA,Torres JA. 1995. Survey and ecological studies of the termites (Isoptera: Kalotermitidae) of Mona Island. Florida Entomologist 78: 305-313.

411 Jouquet P, Traoré S, Choosai C, Hartmann C, Bignell D. 2011. Influence of termites on 
ecosystem functioning: ecosystem services provided by termites. European Journal of Soil Biology 47: 215-222. DOI: 10.1016/j.ejsobi.2011.05.005

414 Lachat T, Wermelinger B, Gossner MM, Bussler H, Isacsson G, Müller J. 2012. Saproxylic 415 beetles as indicator species for dead-wood amount and temperature in European beech forests. Ecological Indicators 23: 323-331. DOI: 10.1016/j.ecolind.2012.04.013

417 Lorimer CG, Dahir SE, Nordheim EV. 2001. Tree mortality rates and longevity in mature and old-growth hemlock-hardwood forests. Journal of Ecology 89: 960-971. DOI:

Lott EJ, Bullock SH, Solis-Magallanes A. 1987. Floristic diversity and structure of upland 10.1111/j.1365-2745.2001.00619.x

Maass JM, Martínez-Yrízar A, Patiño C, Sarukhán J. 2002. Distribution and annual net accumulation of above-ground dead phytomass and its influence on throughfall quality in a Mexican tropical deciduous forest ecosystem. Journal of Tropical Ecology 18: 821-834

Martínez-Ramos M, Alvarez-Buylla E, Sarukhan J, Piñero D. 1988. Treefall age determination and gap dynamics in a tropical forest. Journal of Ecology 76: 700-716. DOI: $10.1017 / \mathrm{S} 0266467402002535$

Martius C. 1997. Decomposition of Wood. In: Junk WJ ed. The Central Amazon Floodplain. Ecological Studies (Analysis and Synthesis). Berlin: Springer, 267-276. termites: ecology, biogeography, and ecosystem impacts. Ecological Entomology 40: 199210. DOI: $10.1111 /$ een. 12185

Méndez-Montiel JTM, Martínez-Equihua A. 2001. Diversidad y manejo de los termes de México (Hexapoda, Isoptera). Acta Zoológica Mexicana, 1: 173-187. 
435 Moe SR, Mobæk R, Narmo AK. 2009. Mound building termites contribute to savanna

436 vegetation heterogeneity. Plant Ecology 202: 31-40. DOI: 10.1007/s11258-009-

$437 \quad 9575-6$

438 Murphy PG, Lugo AE. 1986. Ecology of tropical dry forest. Annual Review of Ecology and

439 Systematics 17: 67-88. DOI: 10.1146/annurev.es.17.110186.000435

440 Nickle DA, Collins MS. 1988. The termite fauna (Isoptera) in the vicinity of Chamela,

441 State of Jalisco, Mexico. Folia Entomologica Mexicana 77: 85-122.

442 Ohkuma M. 2003. Termite symbiotic systems: efficient bio-recycling of lignocellulose.

443 Applied Microbiology and Biotechnology 61: 1-9. DOI: 10.1007/s00253-002-1189-z

444 Palace M, Keller M, Hurtt G, Frolking S. 2012. A review of aboveground necromass in

445 tropical forests. In: Sudarshana P, Nageswara-Rao M, Soneji JR eds. Tropical Forests.

446 InTech Open 215 -252. Published online at: http://www.intechopen.com/books/tropical-

447 forests

448 Pfeifer M, Lefebvre V, Turner E, Cusack J, Khoo M, Chey VK, Peni M, Ewers RM. 2015.

449 Deadwood biomass: an underestimated carbon stock in degraded tropical forests?.

450 Environmental Research Letters 10: 044019. DOI: 10.1088/1748-9326/10/4/044019

451 Rice AH, Pyle EH, Saleska SR, Hutyra L, Palace M, Keller M, De Camargo PB,

452 Portilho K, Marques DF, Wofsy SC. 2004. Carbon balance and vegetation dynamics in an

453 old-growth Amazonian forest. Ecological Applications 14: 55-71. DOI: 10.1890/02-6006

454 Rodríguez-Palafox A, Corona AM. 2002. Lista de artrópodos de la región de Chamela,

455 Jalisco, México. In: Noguera F, Vega-Rivera JH, García-Aldrete AN, Quesada M eds.

456 Historia Natural de Chamela, México: Instituto de Biología-UNAM, 203-232.

457 Romero GQ, Gonçalves-Souza T, Vieira C, Koricheva J. 2015. Ecosystem engineering 
effects on species diversity across ecosystems: a meta-analysis. Biological Reviews 90: 877-890. DOI: 10.1111/brv.12138

460 461 462

Rzedowski J. 1978. Vegetación de México. Mexico DF: Editorial Limusa.

SAS. 2017. SAS Software, version 9.4. Cary, NC: SAS Institute

Segura G, Balvanera P, Durán E, Pérez A. 2003. Tree community structure and stem mortality along a water availability gradient in a Mexican tropical dry forest. Plant Ecology 169: 259-271. DOI: 10.1023/A:1026029122077

Swift MJ, Healey IN, Hibberd JK, Sykes JM, Bampoe V, Nesbitt ME. 1976. The decomposition of branch-wood in the canopy and floor of a mixed deciduous woodland. Oecologia 26: 139-149. DOI: 10.1007/BF00582892

Ulyshen MD. 2014. Interacting effects of insects and flooding on wood decomposition. PloS one 9: e101867. DOI: 10.1371/journal.pone.0101867

Vasconcellos A. 2010. Biomass and abundance of termites in three remnant areas of Atlantic Forest in northeastern Brazil. Revista Brasileira de Entomologia 54: 455-461. DOI: $10.1590 / \mathrm{S} 0085-56262010000300017$ 
Figure 1 (on next page)

Density of trees associated with termites in Chamela

(A) Comparison of the density of living trees with termites in two habitats. (B) Comparison of the density of standing dead trees with termites in two habitats. LSMeans $( \pm \mathrm{SE})$ are shown in bars: grey bars for deciduous forest (DF); black bars for riparian forest (RP). Density values are reported as individuals per $\mathrm{m}^{2}$. Different letters indicate significant differences $(P<0.005)$ between the density across habitats and years. 
Figure 2 (on next page)

Proportion of trees associated with termites in Chamela

(A) Comparison of the proportion of living trees with termites in two habitats. (B) Comparison of the proportion of standing dead trees with termites in two habitats. LSMeans $( \pm S E)$ are shown in bars: grey bars for deciduous forest (DF); black bars for riparian forest (RP). Values are the percentage of trees with termites. Different letters indicate significant differences $(P<0.005)$ between the density across habitats and years. 


\section{Table $\mathbf{1}$ (on next page)}

Table 1. Habitat parameters 


\section{Deciduous Forest Riparian Forest Deciduous Forest Riparian Forest}

\section{Living trees}

Total density

$0.164 \pm 0.058^{\mathrm{ab}}$

$0.090 \pm 0.044^{\mathrm{a}}$

$0.513 \pm 0.100^{\text {cd }}$

$0.352 \pm 0.085^{\mathrm{bc}}$

Size class I density

$0.046 \pm 0.017^{\mathrm{ab}}$

$0.025 \pm 0.012^{\mathrm{bc}}$

$0.268 \pm 0.041^{\mathrm{A}}$

$0.202 \pm 0.036^{\mathrm{A}}$

Size class II density

$0.070 \pm 0.021^{\mathrm{a}}$

$0.042 \pm 0.016^{\mathrm{ab}}$

$0.184 \pm 0.034^{\mathrm{A}}$

$0.106 \pm 0.026^{\mathrm{AB}}$

Size class III density

$0.026 \pm 0.013^{\text {bd }}$

$0.009 \pm 0.007^{\mathrm{c}}$

$0.036 \pm 0.015^{\mathrm{B}}$

$0.029 \pm 0.031^{\mathrm{BC}}$

Size class IV density

$0.018 \pm 0.010^{\mathrm{cd}}$

$0.014 \pm 0.009^{\mathrm{cd}}$

$0.025 \pm 0.012^{\mathrm{BC}}$

$0.015 \pm 0.009^{C}$

\section{Standing dead trees}

Total density

Size class I density

Size class II density

Size class III density

Size class IV density
$0.060 \pm 0.013^{\mathrm{ab}}$

$0.019 \pm 0.006^{\mathrm{ac}}$

$0.026 \pm 0.068^{\mathrm{a}}$

$0.010 \pm 0.004^{b c}$

$0.005 \pm 0.003^{b}$
$0.025 \pm 0.008^{c}$

$0.087 \pm 0.016^{\mathrm{a}}$

$0.047 \pm 0.012^{\mathrm{b}}$

$0.008 \pm 0.004^{\mathrm{bc}}$

$0.031 \pm 0.007^{\mathrm{A}}$

$0.013 \pm 0.005^{\mathrm{AB}}$

$0.011 \pm 0.004^{\mathrm{bc}}$

$0.048 \pm 0.009^{\mathrm{A}}$

$0.028 \pm 0.007^{\mathrm{A}}$

$0.003 \pm 0.002^{\mathrm{b}}$

$0.003 \pm 0.002^{\mathrm{B}}$

$0.005 \pm 0.003^{\text {B }}$

$0.002 \pm 0.001^{\mathrm{b}}$

$0.001 \pm 0.001^{\mathrm{B}}$

$*$ Density values are expressed in tree $/ \mathrm{m}^{2}$. Different letters indicate significant differences

$(P<0.05)$. Size classes: I, saplings (DBH $\leq 5 \mathrm{~cm})$; II, juveniles $(\mathrm{DBH}>5 \leq 15 \mathrm{~cm})$; III, medium adults $(\mathrm{DBH}>15 \leq 25 \mathrm{~cm})$; IV, large adults $(\mathrm{DBH}>25 \mathrm{~cm})$. 


\section{Figure $\mathbf{3}$ (on next page)}

Distribution of the density of trees associated with termites in different diameter size classes in Chamela

(A) Density of living trees with termites in 2004. (B) Density of living trees with termites in 2009. (C) Density of standing dead trees with termites in 2004. (D) Density of standing dead trees in 2009. LSMeans ( \pm SE) are shown in bars: grey bars for deciduous forest (DF); black bars for riparian forest (RP). Diameter size classes are indicated by Roman numerals: I, saplings (DBH $\leq 5 \mathrm{~cm}$ ); II, juveniles (DBH $>5 \leq 15 \mathrm{~cm}$ ); III, medium adults (DBH $>15 \leq 25$ $\mathrm{cm}$ ); IV, large adults (DBH > $25 \mathrm{~cm}$ ). Statistical analyses were performed for each year (2004 and 2009). Different letters indicate significant differences $(P<0.005)$ across size classes and habitats. 


\section{Figure 4 (on next page)}

Relationship between the density of trees associated with termites and the density of standing dead trees in Chamela

Density was estimated as individuals per $\mathrm{m}^{2}$. Grey dashed lines indicate the $95 \%$ confidence interval. The estimated linear regression equation is $y=1.9126 x+0.0465(n=20)$. 


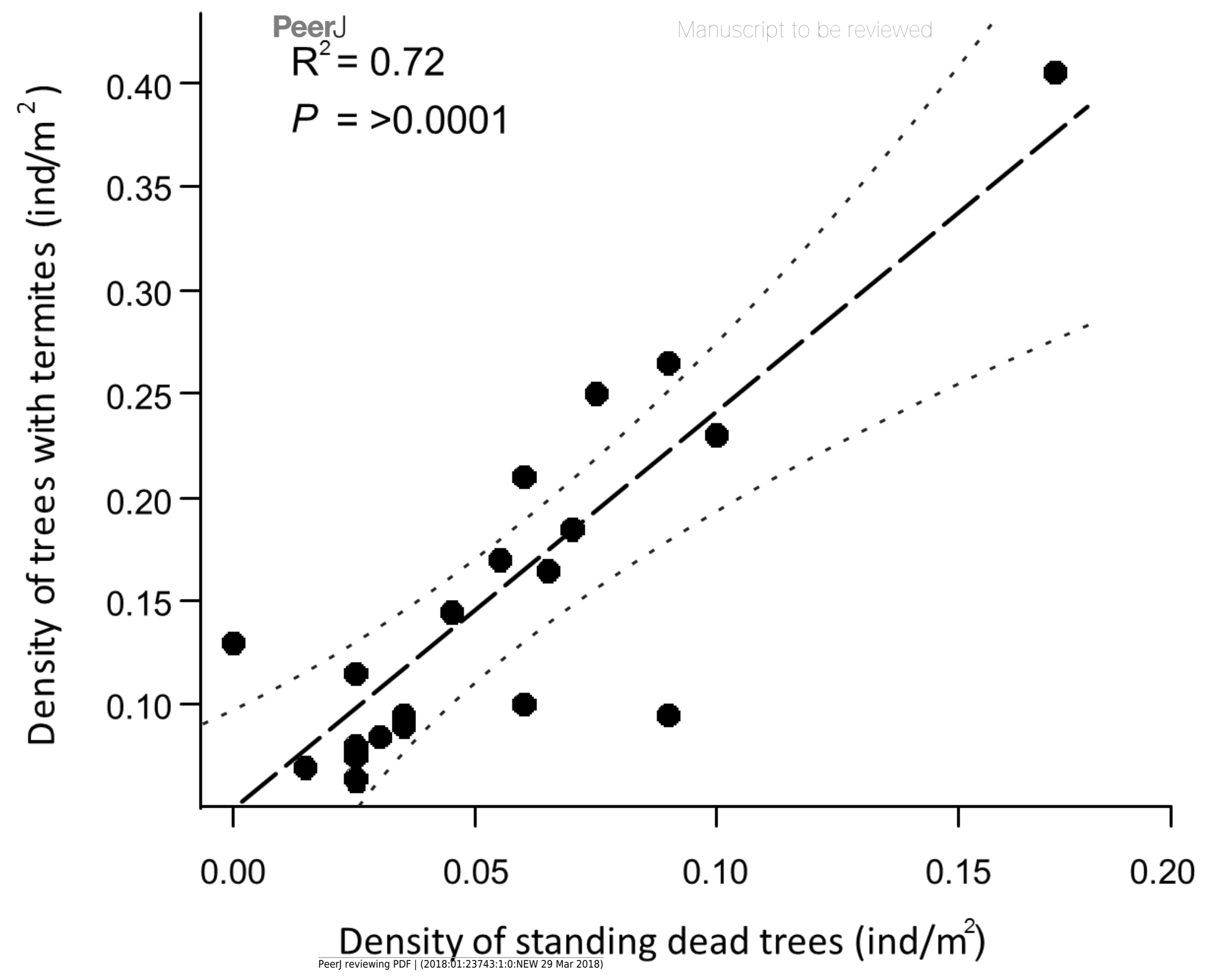

